Article

\title{
FATTY ACIDS, PHENOLIC COMPOUNDS AND ANTIOXIDANT CAPACITY OF THE SEEDS FROM NINE GRAPE CULTIVARS (VITIS VINIFERA L.)
}

\section{ÁCIDOS GORDOS, COMPOSTOS FENÓLICOS E ACTIVIDADE ANTIOXIDANTE DE GRAINHAS PROVENIENTES DE NOVE CASTAS (VITIS VINIFERA L.)}

\author{
Ali Guler ${ }^{1, *}$, Demet Yildiz Turgut ${ }^{2}$ \\ ${ }^{1}$ Viticulture Research Institute, Atatürk Strt, Horozköy Ave., 45125 Yunusemre/Manisa, Turkey. \\ ${ }^{2}$ Bati Akdeniz Agricultural Research Institute, Demircikara Strt. Paşa Kavakları Ave. No:11 Antalya, Turkey. \\ * Corresponding author: Tel: +902362111071, e-mail: aligguler@gmail.com \\ (Received 14.06.2021. Accepted 13.09.2021)
}

\section{SUMMARY}

Seeds are one of the main parts of the grapes, and they contain important constituents such as polyphenols, lipids, proteins and carbohydrates. In this study, oil contents, fatty acid composition, total phenolic content, total flavonoid content, monomeric flavan-3-ols and antioxidant capacities of nine grape seeds from nine cultivars were investigated. The correlations between the analyzed parameters were also examined. The oil contents of seeds ranged from 4.96 to $13.35 \%$. Linoleic acid was the predominant fatty acid in the seeds, and it was followed by oleic acid, palmitic acid, stearic acid, linolenic acid, 11-eicosenoic acid and arachidic acid. Total phenolic and total flavonoid contents were 646.50-1120.78 mg GAE/g and 336.69-589.85 mg CE/g, respectively. 'Italia' seeds had the highest antioxidant capacity for DPPH and CUPRAC assays while 'Cabernet Sauvignon' seeds had the lowest one. The (-)-epigallocatechin, (+)-catechin, (-)-epigallocatechin gallate, (-)-epicatechin and (-)-epicatechin gallate contents in the seeds varied from 1.23 to $6.53 \mathrm{mg} / \mathrm{g}, 11.61$ to 80.20 $\mathrm{mg} / \mathrm{g}, 0.21$ to $0.51 \mathrm{mg} / \mathrm{g}, 2.78$ to $48.26 \mathrm{mg} / \mathrm{g}$ and 0.08 to $1.50 \mathrm{mg} / \mathrm{g}$, respectively. The (+)-catechin and (-)-epicatechin were the major flavan-3-ol compounds in the grape seeds. Significant correlations were found between total phenolic content, total flavonoid, RSA (DPPH Radical scavenging activity), CUPRAC (Cupric reducing antioxidant capacity) and flavan-3-ols. Consequently, the current study findings support previous information that grape seeds are an important source of antioxidants as well as unsaturated fatty acids, which have positive effects on human health.

\section{RESUMO}

As grainhas são uma das principais partes da uva e contêm polifenóis, lípidos, proteínas e hidratos de carbono. Neste estudo, foram avaliados o teor de óleo, a composição em ácidos gordos, os teores de fenólicos totais, teores de flavonóides totais, de 3-flavanóis monoméricos e a atividade antioxidante em grainhas de nove castas. As correlações entre os parâmetros analisados foram também examinadas. O teor de lípidos das grainhas variou de 4,96 a 13,35\%. O ácido linoléico foi o ácido gordo predominante nas grainhas, seguido pelo ácido oleico, ácido palmítico, ácido esteárico, ácido linolénico, ácido 11-eicosenoico e ácido eicosanoico. Os teores de compostos fenólicos e flavonóides totais foram de 646,50-1120,78 mg GAE/ge e de 336,69-589,85 mg EC/g, respetivamente. As grainhas da casta 'Itália' apresentaram a maior capacidade antioxidante para os ensaios DPPH e CUPRAC, enquanto as grainhas de 'Cabernet Sauvignon' apresentaram os valores mais baixos. Os teores de (-)-epigalhocatequina, (+)-catequina, (-)-epigalhocatequina galhato, (-)-epicatequina e (-)-epicatequina galhato nas grainhas variaram de 1,23 a $6,53 \mathrm{mg} / \mathrm{g}, 11,61$ a $80,20 \mathrm{mg} / \mathrm{g}, 0,21$ a $0,51 \mathrm{mg} / \mathrm{g}, 2,78$ a $48,26 \mathrm{mg} / \mathrm{ge} 0,08$ a 1,50 $\mathrm{mg} / \mathrm{g}$, respetivamente. A (+)-catequina e (-)-epicatequina foram os principais 3-flavanóis nas grainhas. Foram encontradas correlações significativas entre o teor de polifenóis totais totais, flavonóides, RSA, CUPRAC e 3-flavanóis. Consequentemente, os resultados deste estudo corroboram resultados anteriores, evidenciando que as grainhas são uma fonte importante de antioxidantes, bem como de ácidos gordos insaturados, que têm efeitos positivos na saúde humana.

Keywords: Seed extracts, fatty acids, polyphenols, antioxidant activity. Palavras-chave: Extratos de grainha, ácidos gordos, polifenóis, atividade antioxidante.

\section{INTRODUCTION}

Seeds are one of the main parts of the grapes, and their number and weight change depend on the cultivar. Seeded grapes are used more as table and in the wine production. In addition, some cultivars of them can be dried in grape grower countries. Recently, grape seeds recycled from winery and other grape processing industries wastes are used to obtain some products such as seed oil, extract and antioxidants. The rising of scientific findings related to positive effects on human health of grape seed products has increased their demands and productions. The most common of these products are grape seed oils and extracts.

Grape seeds contain polyphenols, lipid, protein and carbohydrates (Shi et al., 2003). In the ancient times,

(c) Ali Guler and Demet Yildiz Turgut, 2021.

This is an Open Access article distributed under the terms of the Creative Commons Attribution License (https://creativecommons.org/licenses/by/4.0), which permits unrestricted use, distribution, and reproduction in any medium, provided the original work is properly cited 
grape seed oil was called "royal oil" because of its curative effects. Nowadays, the grape seed oil is used in human diet, as well as in some non-food industries such as pharmaceutics and cosmetics. The grape seeds oil content range from $6 \%$ to $20 \%$ depending on cultivar (Martin et al., 2020). The grape seed oil is rich in unsaturated fatty acids (UFAs), such as linoleic and oleic acid, and UFAs constitute approximately $90 \%$ of total seed fatty acid contents (Sabir et al., 2012; Martin et al., 2020). Polyunsaturated fatty acids (PUFAs), monounsaturated fatty acids (MUFAs) and saturated fatty acids (SFAs) comprise $47.48-77.12 \%$, $13.77-28.53 \%$ and $8.92-24.04 \%$ of the total fatty acid contents in grape seed oil, respectively (Tangolar et al., 2009; Wen et al., 2016; Al Juhaimi et al., 2017).

Grape seeds are considered as a rich source in terms of polyphenols, especially flavonoids. These are monomeric flavan-3-ols (catechin, epicatechin, epicatechin gallate and epigallocatechin), procyanidin dimers, trimers and more highly polymerised procyanidins (Mandic et al., 2008, Yemis et al., 2008). The grape seeds may contain $60-70 \%$ of total extractable grape phenolic compounds (Nawaz et al., 2006). The monomeric flavan-3-ols, dimeric, trimeric, and tetrameric procyanidins, as well as highly polymerised procyanidins, have anti-aging, anti-mutagenic, anti-atherogenic and anti-viral effects (Shi et al., 2003). In addition, these flavonoids show significant preventive effects against different cancer types, cardiovascular diseases and several dermal disorders owing to their high antioxidant activity (Li et al., 2008). Catechin and epicatechin are the major monomeric flavan-3-ols and they have hydroxyl, peroxyl, superoxide, and DPPH radical scavenging activities (Y1lmaz and Toledo, 2004). According to Nakao et al. (1998), these compounds are also able to peroxyl scavenging activity 10 times higher than L-ascorbate and beta-carotene.

The objectives of the current study are the assessment of oil content, fatty acid compositions, phenolic compounds and antioxidant capacity of nine grape seeds from grapevine cultivars (Vitis vinifera L.) widely grown in Turkey. In the seeds, total oil, PUFA, MUFA and SFA contents, total phenolic content (TP), total flavonoids (TF) and individual monomeric flavan-3-ols were investigated. RSA and CUPRAC methods were performed to examine the samples' antioxidant properties. In addition, the correlations between TP, TF, RSA and CUPRAC were also evaluated.

\section{MATERIALS AND METHODS}

\section{Chemicals}

Petroleum ether, potassium hydroxide, n-hexane, methanol, Folin-Ciocalteu reagent, formic acid and ethyl alcohol were purchased from Merck (Darmstadt, Germany). Aluminum chloride, sodium nitrite, sodium hydroxide, 2,2-diphenyl-1-picrylhydrazyl (DPPH), Trolox (6-hydroxy-2,5,7,8-tetramethylchroman-2-carboxyli c acid), cupper (II) chloride dihydrate, neocuproine, ammonium acetate, potassium phosphate monobasic and methanol HPLC gradient grade were obtained from Sigma-Aldrich (St. Louis, Missouri, USA).

Gallic acid, epicatechin and (-)-epigallocatechin were purchased from Sigma-Aldrich (St. Louis, Missouri, USA). (+)-Catechin and $(-)$-epigallocatechin gallate were obtained from Fluka (St. Louis, MO, USA). (-)-Epicatechin gallate and were purchased from Alfa Asear (Karlsruhe, Germany).

\section{Grape seed samples}

Nine grape cultivars (Vitis vinifera L.) including 'Ece' (newly hybrid grape variety, registered on the Turkish national grape list) 'Cardinal', 'Royal', 'Michele Palieri', 'Mevlana', 'Red Globe', 'Italia', 'Alphonse Lavallee' and 'Cabernet Sauvignon' were collected from Manisa Viticulture Research Institute grape collection vineyard in 2019 . The harvest was conducted at 20-30 maturity index for eight table grapes. The Cabernet Sauvignon grapes were harvested at 22.00 brix. Harvested grapes were quickly carried to laboratory, manually crushed and seeds were separated. These seeds were washed and dried at $30{ }^{\circ} \mathrm{C}$ under vacuum conditions. Then, dried seeds were stored at $-20{ }^{\circ} \mathrm{C}$ until analysis.

\section{Grape seed oil extraction}

The dried grape seeds were ground with a grinder (Retsch Grindomix GM200, Retsch GmbH \& Haan, Germany) before oil extraction. The seed oils were extracted with petroleum ether by using Soxhlet method (AOAC, 2005). The oil content was expressed as a percentage of the dry matter.

\section{Extraction of polyphenols}

The extraction of polyphenols was performed according to Shi et al. (2003) with slight modifications. The grounded grape seeds $(4 \mathrm{~g})$ were extracted with hydroalcoholic solution $(50 \% \mathrm{v} / \mathrm{v})$. The solvent and solid phase ratio was set as 7.5:1. First, the grape seeds were sonicated (Kudos, SK7210HP ultrasonic bath, China) for $15 \mathrm{~min}$, and then shaken at $150 \mathrm{rpm}$ at $65^{\circ} \mathrm{C}$ for $90 \mathrm{~min}$ (Nuve, ST 30 shaker water bath, Turkey). The mixture was centrifuged (Nuve, NF 400 centrifuge, Turkey) at $2000 \mathrm{rpm}$ for $6 \mathrm{~min}$ and then the supernatant was separated. Then, this procedure was performed a second time. The obtained grape seed extracts were diluted with methanol as required and then used for the determination of total phenolic and flavonoid contents, antioxidant capacity and individual phenolic compounds. The extraction procedure was repeated in triplicate. 


\section{Fatty acid analyses}

The fatty acids of oil samples were converted to their methyl esters using potassium hydroxide $2 \mathrm{~N}$ in methanol and n-hexane according to Da Porto et al. (2012) for the determination of fatty acid composition. The fatty acids (palmitic, stearic, arachidic, linoleic, linolenic, oleic, and 11-eicosenoic acids) methyl esters were analyzed by using an Agilent 7890A-5975C gas chromatography coupled to flame ionization detector and to a mass selective detector (Agilent 5975C) (GC-MS-FID). Fatty acid separations were performed on a capillary column (HP INNOWax; $60.0 \mathrm{~m} \times 0.25 \mathrm{~mm} \times 0.25$ $\mu \mathrm{m})$. Helium was used as carrier gas at a flow rate of $0.8 \mathrm{~mL} / \mathrm{min}$. Injector and detector temperatures were at $250{ }^{\circ} \mathrm{C}$ and $260{ }^{\circ} \mathrm{C}$, respectively. The oven temperature was programmed from 150 to $230{ }^{\circ} \mathrm{C}$ at $2{ }^{\circ} \mathrm{C} / \mathrm{min}$, and then maintained at $230^{\circ} \mathrm{C}$ for $10 \mathrm{~min}$. The injection volume and split ratio were $1 \mu \mathrm{L}$ and $40: 1$, respectively. The percentages of fatty acids was calculated from their corresponding integration data. MS spectra were monitored between 35-450 AMU and the ionization mode used was electronic impact at $70 \mathrm{eV}$. The identification of individual fatty acids was achieved by comparison of their retention times and mass spectra with Mass Spectral Library (WILEY7N, NIST05, OIL ADAMS).

\section{Total phenolic content}

Determination of the total phenolic content (TP) of the samples was based on the Folin-Ciocalteu colorimetric method (Singleton and Rossi, 1965). The absorbance was measured using a Thermo scientific, Multiskango spectrophotometer (Finland) at $760 \mathrm{~nm}$. The analytic standard was gallic acid, and results were expressed as mg gallic acid equivalent (GAE) in g sample. The calibration curve was drawn by using $5-50 \mathrm{mg} / \mathrm{L}$ standard concentrations.

\section{Flavonoid Assay}

The flavonoid content was determined according to aluminum chloride method (Zhishen et al., 1999). Briefly, $1 \mathrm{~mL}$ extract was diluted with $4 \mathrm{~mL}$ distilled water, and $0.3 \mathrm{~mL}$ sodium nitrite $(5 \%)$ was added on. After $5 \mathrm{~min}$ incubating, $0.3 \mathrm{~mL}$ aluminum chloride $(10 \%)$ was added. The following $6^{\text {th }} \mathrm{min}, 2$ $\mathrm{mL} 1 \mathrm{M}$ sodium hydroxide was also added to and the volume was adjusted to $10 \mathrm{~mL}$ with distilled water. The absorbance was read at $510 \mathrm{~nm}$ in a spectrophotometer (Thermo scientific, Multiskango, Finland). The results were expressed as $\mathrm{mg}$ $(+)$-catechin equivalent $(\mathrm{CE})$ per $\mathrm{g}$.

\section{DPPH• radical scavenging activity assay}

2,2-Diphenyl-1-picrylhydrazyl (DPPH) radical scavenging activity (RSA) assay was performed according to a previous study (Lima et al., 2014). First, $1.0 \mathrm{mM}$ DPPH• radical solution was prepared in methanol and diluted with distilled water to the absorbance until $0.900 \pm 0.05$. The diluted $0.1 \mathrm{~mL}$ sample was added to $2.9 \mathrm{~mL}$ radical solution and the absorbance was measured at times $\mathrm{t}=0$ and $\mathrm{t}=30$ min (after incubation in dark condition). The sample absorbance values were measured using a Uv-vis spectrophotometer (Thermo scientific, Multiskango, Finland) at $517 \mathrm{~nm}$. Trolox was used as analytical standard and the results were expressed as mmol Trolox equivalent (TE) per $\mathrm{g}$.

\section{CUPRAC assay}

The CUPRAC (Cupric reducing antioxidant capacity) assay described by Apak et al. (2004) and modified for adaptation to grape products by Callaghan et al. (2013) was utilized. First, $150 \mu \mathrm{L}$ of $1 \mathrm{M}$ ammonium acetate, $7.5 \mathrm{mM}$ neocuproine, and $10 \mathrm{mM}$ copper (II) chloride dehydrate were added to $150 \mu \mathrm{L}$ diluted samples. Then, the mixture was incubated at room temperature for $30 \mathrm{~min}$. Thereafter, the absorbance was measured at $450 \mathrm{~nm}$. Distilled water was used as a blank. The results were calculated by using the calibration curve and indicated as mmol TE per $\mathrm{g}$.

\section{Individual phenolic compounds}

An Agilent 1260 HPLC was used for quantifying the individual flavan-3-ol compounds. The system was equipped with a diode-array UV detector (DAD). It consisted of a quaternary pump, a degasser, an auto sampler and a column oven. Agilent lab advisor chemstation software was used. The HPLC analysis of the phenolic compounds was performed according to Bucic-Kocic et al. (2009) with slightly modifications. The external standards were used for the quantification of the (+)-catechin (CA), (-)-epigallocatechin (EGC), (-)-epigallocatechin gallate (EGCG), (-)-epicatechin (EC) and $(-)$-epicatechin gallate (ECG) in the seed extracts. C18 ODS column $(250 \times 4.6 \mathrm{~mm}, 5 \mu \mathrm{m})$ was used for the separation (Agilent), and the oven temperature was set to $30^{\circ} \mathrm{C}$. Grape seed extracts were diluted with HPLC gradient grade water and filtered through $0.45 \mu \mathrm{m}$ PTFE filter before injection. Flow rate was set at $0.8 \mathrm{~mL} / \mathrm{min}$, and the injection volume was 20 $\mu \mathrm{L}$. In the gradient elution, mobile phase A was $0.2 \%$ formic acid and B 100\% HPLC gradient grade methanol. Gradient elution program was as follows: the initial elution $5 \% \mathrm{~B}$, followed $30 \mathrm{~min}$ by linear gradient from $5 \%$ to $80 \% \mathrm{~B}, 3$ min isocratic elution step $80 \% \mathrm{~B}$ and 2 min linear gradient elution to $5 \%$ B. Then, 3 min 5\% B isocratic elution was performed for returning to initial condition. The phenolic compounds of the samples were identified by comparing their retention times and spectra with those of analytical standards at $280 \mathrm{~nm}$ wavelength. The results were calculated through the calibration curves and expressed as $\mathrm{mg} / \mathrm{g}$ seed extract. Chromatographic analyses were performed in triplicate.

\section{Statistical analysis}

One-way variance analysis (ANOVA) was performed, and Duncan multiple comparison test 
was made to compare the means when significant differences were found $(\mathrm{p} \leq 0.05)$. Pearson correlation coefficients were calculated to examine the relationships between total phenolic content, flavonoids, individual polyphenols and antioxidant capacities.

\section{RESULTS AND DISCUSSION}

\section{Oil contents of grape seeds}

The oil content of the seeds obtained from the nine cultivars are indicated in Figure 1. Significant statistical differences were observed in the oil yields of the seeds $(p \leq 0.05)$. The oil contents ranged from $4.96 \%$ (Cardinal) to $13.35 \%$ (Italia). Beveridge et al. (2005) found that the seed oil contents of different grape cultivars varied from 6.64 to $11.17 \%$ obtained by petroleum ether extraction. In another study, Koç et al. (2019) found that oil contents varied between $6.93 \%$ and $8.80 \%$ in grape seeds. The findings of the present study are in partial agreement with the results of the aforementioned works. On the other hand, Baydar et al. (2007) reported that the seeds oil contents obtained from Turkish grape cultivars (Kalecik Karası, Narince, Emir, Hasandede) ranged from $12.35 \%$ to $16.00 \%$. Sabir et al. (2012) reported the oil contents of 'Red Globe', 'Cardinal', 'Royal', 'Italia' and 'Alphonse Lavallee' cultivars as $14.21 \%$, $11.33 \%, 14.32 \%, 22.37 \%$ and $13.30 \%$, respectively. In another study, Ovcharova et al. (2016) stated that the oil contents of the four Bulgarian grape seeds ranged between 11.6 and $16.5 \%$. Their results were higher than those of the current study. Such difference may be due to several factors such as extraction methods, types of solvent, harvest time, grape cultivar, location and environmental conditions.

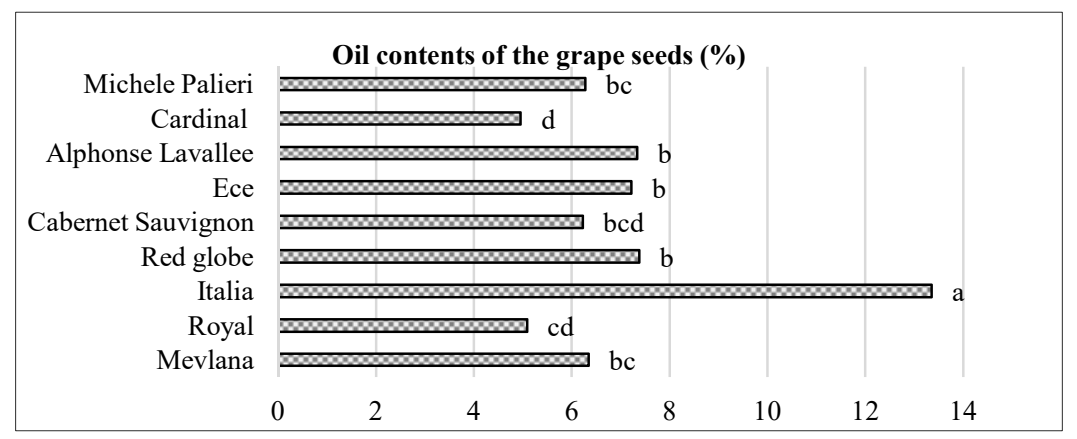

Figure 1. The oil contents of the grape seeds.

Seven fatty acids were detected in all cultivars and their contents are illustrated in Table I. In order of descending percentages, they were linoleic acid > oleic acid $>$ palmitic acid $>$ stearic acid $>$ linolenic acid $>11$-eicosenoic $>$ arachidic acid. The results show significant variations in the fatty acid composition between cultivars. The fatty acids composition ranged from 11.21 to $14.65 \%$ SFAs, from 16.32 to $25.92 \%$ MUFAs, and from 61.41 to $69.43 \%$ PUFAs. The predominant SFA in all cultivars was palmitic acid, which varied between $7.71 \%$ ('Michele Palieri') and 10.02\% ('Ece'). Stearic acid was the second most abundant SFA, ranging from $3.29 \%$ in 'Alphonse Lavallee' to $5.23 \%$ in 'Cabernet Sauvignon'. Another SFA, arachidic acid, was detected in low percentages $(0.12-0.19 \%)$ in all cultivars. Linoleic acid was the most abundant PUFA in all cultivars, ranging from $60.88 \%$ in 'Cabernet Sauvignon' to $69.08 \%$ in 'Red Globe'. Then, the linolenic acid ranged from $0.35 \%$ (Red Globe) to $13.9 \%$ (Cabernet Sauvignon). The main MUFA in the seed oils was oleic acid. The highest oleic acid content was found in 'Red Globe' (25.73\%), while the lowest content was determined in 'Cabernet Sauvignon' (16.17\%). 11-Eicosenoic acid varied between $0.14 \%$ and $0.21 \%$. These findings fall within similar ranges reported in previous studies (Baydar et al., 2007; Tangolar et al., 2009; Sabir et al., 2012; Wen et al., 2016).

The seed oils of all grape cultivars studied were very rich in UFAs. High contents of UFAs is an important factor for the nutritional quality of the oil, prevention of cardiovascular disorders, reducing low-density lipoprotein and raising high-density lipoprotein (Beveridge et al., 2005; Tangolar et al., 2009). Among the investigated grape cultivars, 'Red Globe' and 'Cabernet Sauvignon' had the highest MUFAs (25.92\%) and PUFAs (69.43\%), respectively.

In addition, 'Cabernet Sauvignon' and 'Red Globe' were also the cultivars with higher percentages of linoleic acid and oleic acid, respectively. Wen et al. (2016) reported PUFAs contents of 'Cabernet Sauvignon' cultivar as $73.85 \%$. However, this value is higher than those obtained in the present. Conversely, the oleic acid content found in the current work is higher than that reported by Sabir et al. (2012) for the 'Red Globe' cultivar (18.10\%). Variation in fatty acid composition of grape seed oils 
can be ascribed to cultivar, environmental factors, geographical conditions and oil extraction methods.

\section{Total phenolic and flavonoid contents}

TP contents of the grape seeds ranged between 646.50 and $1120.78 \mathrm{mg} \mathrm{GAE} / \mathrm{g}$, and significant differences among the seeds were observed $(\mathrm{p} \leq 0.05)$. These TP variations of the samples are shown in Figure 2.

Table I

The fatty acid compositions in the seeds (\%)

\begin{tabular}{|c|c|c|c|c|c|c|c|c|c|}
\hline Cultivars & Ece & Cardinal & Royal & $\begin{array}{c}\text { Michele } \\
\text { Palieri } \\
\end{array}$ & Mevlana & Red Globe & Italia & $\begin{array}{c}\text { Alphonse } \\
\text { Lavallee }\end{array}$ & $\begin{array}{c}\text { Cabernet } \\
\text { Sauvignon }\end{array}$ \\
\hline Palmitic acid & $10.02 \pm 0.41^{\mathrm{a}}$ & $9.44 \pm 0.01^{\mathrm{b}}$ & $8.80 \pm 0.08^{\mathrm{cd}}$ & $7.71 \pm 0.09^{f}$ & $9.21 \pm 0.04^{\mathrm{bc}}$ & $8.03 \pm 0.01^{\mathrm{ef}}$ & $6.65 \pm 0.02^{\mathrm{g}}$ & $8.38 \pm 0.40^{\text {ed }}$ & $8.65 \pm 0.03^{\mathrm{d}}$ \\
\hline Stearic acid & $4.46 \pm 0.18^{\mathrm{b}}$ & $3.84 \pm 0.01^{\mathrm{d}}$ & $3.81 \pm 0.07^{\mathrm{d}}$ & $3.56 \pm 0.01^{\mathrm{e}}$ & $3.65 \pm 0.02^{\mathrm{e}}$ & $4.02 \pm 0.01^{\mathrm{c}}$ & $4.42 \pm 0.01^{\mathrm{b}}$ & $3.29 \pm 0.07^{\mathrm{f}}$ & $5.23 \pm 0.01^{\mathrm{a}}$ \\
\hline Arachidic acid & $0.17 \pm 0.00^{\mathrm{b}}$ & $0.14 \pm 0.01^{\mathrm{d}}$ & $0.16 \pm 0.01^{\mathrm{c}}$ & $0.14 \pm 0.01^{\mathrm{d}}$ & $0.18 \pm 0.01^{\mathrm{ab}}$ & $0.16 \pm 0.01^{\mathrm{c}}$ & $0.13 \pm 0.01^{\mathrm{d}}$ & $0.12 \pm 0.01^{\mathrm{e}}$ & $0.19 \pm 0.01^{\mathrm{a}}$ \\
\hline Linoleic acid & $63.10 \pm 3.64^{\mathrm{b}}$ & $65.72 \pm 0.04^{\mathrm{a}}$ & $63.66 \pm 2.78^{\mathrm{b}}$ & $64.27 \pm 0.19^{b}$ & $65.55 \pm 0.04^{\mathrm{a}}$ & $60.88 \pm 0.10^{\mathrm{c}}$ & $64.53 \pm 0.36^{\mathrm{b}}$ & $61.95 \pm 0.32^{\mathrm{b}}$ & $69.08 \pm 0.04^{\mathrm{a}}$ \\
\hline Linolenic acid & $0.48 \pm 0.03^{\mathrm{ab}}$ & $0.43 \pm 0.01^{\mathrm{bc}}$ & $0.45 \pm 0.05^{\mathrm{bc}}$ & $0.37 \pm 0.00^{\mathrm{de}}$ & $0.49 \pm 0.01^{\mathrm{ab}}$ & $0.52 \pm 0.02^{\mathrm{a}}$ & $0.26 \pm 0.01 \mathrm{f}$ & $0.40 \pm 0.04^{\mathrm{cd}}$ & $0.35 \pm 0.01^{\mathrm{e}}$ \\
\hline Oleic acid & $21.33 \pm 4.21^{\mathrm{b}}$ & $19.94 \pm 0.01^{\mathrm{c}}$ & $22.68 \pm 2.92^{\mathrm{a}}$ & $23.29 \pm 0.11^{\mathrm{a}}$ & $20.44 \pm 0.05^{\mathrm{c}}$ & $25.73 \pm 0.37^{\mathrm{a}}$ & $23.16 \pm 0.28^{\mathrm{a}}$ & $24.93 \pm 0.33^{\mathrm{a}}$ & $16.17 \pm 0.01^{\mathrm{d}}$ \\
\hline 11-Eicosenoic acid & $0.19 \pm 0.01^{\mathrm{ab}}$ & $0.19 \pm 0.01^{\mathrm{ab}}$ & $0.21 \pm 0.02^{\mathrm{a}}$ & $0.20 \pm 0.01^{\mathrm{a}}$ & $0.20 \pm 0.01^{\mathrm{a}}$ & $0.18 \pm 0.01^{\mathrm{ab}}$ & $0.19 \pm 0.01^{\mathrm{ab}}$ & $0.18 \pm 0.01^{\mathrm{ab}}$ & $0.14 \pm 0.01^{\mathrm{b}}$ \\
\hline PUFA & $63.58 \pm 3.61^{\mathrm{b}}$ & $66.15 \pm 0.02^{\mathrm{a}}$ & $64.21 \pm 2.72^{\mathrm{b}}$ & $64.65 \pm 0.19^{\mathrm{b}}$ & $66.04 \pm 0.04^{\mathrm{a}}$ & $61.41 \pm 0.08^{\mathrm{d}}$ & $64.79 \pm 0.37^{\mathrm{b}}$ & $62.35 \pm 0.27^{\mathrm{c}}$ & $69.43 \pm 0.04^{\mathrm{a}}$ \\
\hline MUFA & $21.52 \pm 4.22^{\mathrm{b}}$ & $20.13 \pm 0.02^{\mathrm{c}}$ & $22.89 \pm 2.89^{\mathrm{a}}$ & $23.49 \pm 0.11^{\mathrm{a}}$ & $20.64 \pm 0.04^{\mathrm{c}}$ & $25.92 \pm 0.38^{\mathrm{a}}$ & $23.35 \pm 0.28^{\mathrm{a}}$ & $25.12 \pm 0.38^{\mathrm{a}}$ & $16.32 \pm 0.01^{\mathrm{d}}$ \\
\hline SFA & $14.65 \pm 0.60^{\mathrm{a}}$ & $13.43 \pm 0.01^{\mathrm{b}}$ & $12.77 \pm 0.16^{\mathrm{c}}$ & $11.41 \pm 0.08^{\mathrm{f}}$ & $13.04 \pm 0.01^{\mathrm{b}}$ & $12.21 \pm 0.01^{\mathrm{d}}$ & $11.21 \pm 0.04^{\mathrm{f}}$ & $11.80 \pm 0.48^{\mathrm{e}}$ & $14.08 \pm 0.03^{\mathrm{a}}$ \\
\hline
\end{tabular}

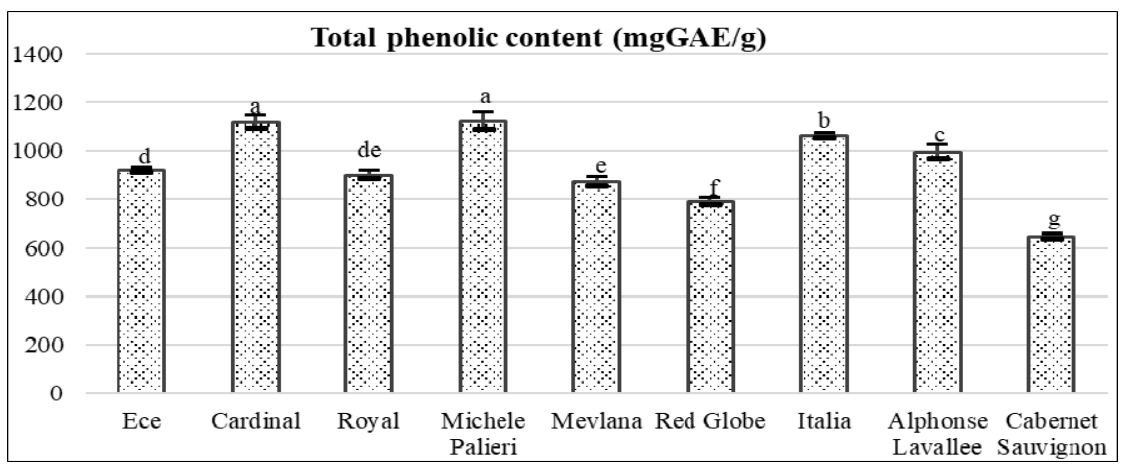

Figure 2. Total phenolic contents of the seeds.

'Michele Palieri' extract had the highest TP content, followed by 'Cardinal' extract whereas 'Cabernet Sauvignon' had the lowest one. The TP contents of the grape seed samples were ranked as follows: 'Michele Palieri' > 'Cardinal' > 'Italia' > 'Alphonse Lavallee' $>$ 'Ece' $>$ 'Royal' $>$ 'Mevlana' $>$ 'Red Globe' > 'Cabernet Sauvignon'. Yemiş et al. (2008) reported that TP contents of 12 different grape seeds ranged from 339.45 to $587.30 \mathrm{mg} \mathrm{GAE} / \mathrm{g}$. In a previous study, it was stated that TP contents varied between 522.49 and $546.50 \mathrm{mg} \mathrm{GAE} / \mathrm{g}$ in three different grape seeds, and TP content of 'Cabernet Sauvignon' seed was $522.49 \mathrm{mg} \mathrm{GAE} / \mathrm{g}$ (Baydar et al., 2011). The findings of the current study are in accordance with these results. However, the obtained values are higher than those found by Shi et al. (2003), Li et al. (2008), Bucic-Kocic et al. (2009) and Coklar (2017). These differences could be caused by cultivar, environmental conditions, extraction solvents and conditions.

The TF content varied among the different grape seeds, ranging from 336.69 to $589.85 \mathrm{mg} \mathrm{CE} / \mathrm{g}$. The significant statistical differences are illustrated in Figure 3.

Makris et al. (2007) reported TF contents between 102.58 and $110.90 \mathrm{mg} \mathrm{CE} / \mathrm{g}$ in red and white grape seeds, representing $99 \%$ of $\mathrm{TP}$. The TF results attained in the current work are considerably higher than the previous study results while $\mathrm{TP} / \mathrm{TF}$ ratios were lower. In another study (Al Juhaimi et al., 2017), the TF contents of 13 grape seeds ranged between 263.53 (Sauvignon Blanc) and $1706.00 \mathrm{mg}$ $\mathrm{CE} / \mathrm{g}$ (Cabernet Sauvignon). Although the TF results in the current study agreed with Al Juhaimi et al. (2017) findings as general, the TF content of 
'Cabernet Sauvignon' seeds was lower. It is thought that these TF differences, as in TP, could result from the influence of many factors such as variety, environmental conditions, extraction solvents and conditions.

\section{Antioxidant capacities of the grape seeds}

Antioxidant capacity, expressed as Trolox equivalent (TEAC), was analysed by two methods (DPPH and CUPRAC), and the obtained results are shown in Table II. The significant statistical differences at $\mathrm{p} \leq 0.05$ level were determined for RSA and CUPRAC values among the samples. The grape seeds showed high scavenging capacity for both DPPH and CUPRAC methods. RSA and CUPRAC were 5.32-9.85 mmol TE/g and 7.94-14.43 mmol TE/g, respectively. 'Italia' seeds had the highest and 'Cabernet Sauvignon' seeds had the lowest antioxidant capacity for both assays. RSA values of the grape seeds decreased in the following order: 'Italia' > 'Cardinal' $>$ 'Alphonse Lavallee' > 'Michele Palieri' > 'Royal' > 'Mevlana' > 'Ece' > 'Red Globe' $>$ 'Cabernet Sauvignon'. CUPRAC values ranking of the seed extracts were similar to RSA ranking except for 'Ece' and 'Mevlana' results. 'Ece' had higher CUPRAC value than 'Mevlana'. Makris et al. (2007) obtained $5.94 \mathrm{mmol} \mathrm{TE} / \mathrm{g}$ for DPPH antiradical activity in red and white grape seeds. These findings are in agreement with the results of Makris et al. (2007). On the other hand, the results are higher than those of previous studies (Y1lmaz and Toledo, 2004; Li et al., 2008; Coklar, 2017), but they are lower than those reported by Yemis et al. (2008). These discrepancies might be caused by differences in grape variety and extraction procedures.

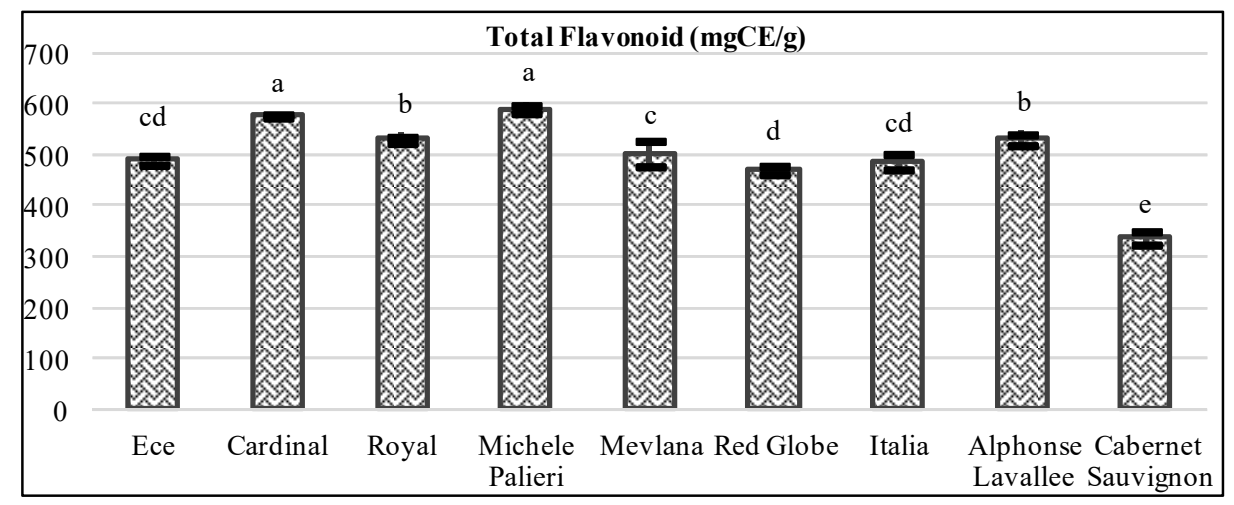

Figure 3. Total flavonoid contents of the seeds

Table II

Antioxidant capacity of the grape seeds and flavan-3-ol monomers

\begin{tabular}{|c|c|c|}
\hline *Cultivars & $\begin{array}{c}\text { RSA } \\
(\mathrm{mmol} \mathrm{TE} / \mathrm{g})\end{array}$ & $\begin{array}{c}\text { CUPRAC } \\
(\mathrm{mmol} \mathrm{TE} / \mathrm{g})\end{array}$ \\
\hline Ece & $7.51 \pm 0.28^{\text {ef }}$ & $11.35 \pm 0.26^{\mathrm{c}}$ \\
\hline Cardinal & $9.48 \pm 0.12^{\mathrm{b}}$ & $13.97 \pm 0.48^{\mathrm{a}}$ \\
\hline Royal & $7.94 \pm 0.22^{\mathrm{d}}$ & $11.70 \pm 0.23^{\mathrm{c}}$ \\
\hline Michele Palieri & $8.93 \pm 0.23^{\mathrm{c}}$ & $12.54 \pm 0.62^{b}$ \\
\hline Mevlana & $7.77 \pm 0.09^{\mathrm{de}}$ & $11.21 \pm 0.15^{\mathrm{c}}$ \\
\hline Red Globe & $7.36 \pm 0.10^{f}$ & $10.65 \pm 0.13^{d}$ \\
\hline Italia & $9.85 \pm 0.04^{\mathrm{a}}$ & $14.43 \pm 0.04^{\mathrm{a}}$ \\
\hline Alphonse Lavallee & $8.94 \pm 0.05^{\mathrm{c}}$ & $12.63 \pm 0.15^{\mathrm{b}}$ \\
\hline Cabernet Sauvignon & $5.32 \pm 0.16^{\mathrm{g}}$ & $7.94 \pm 0.21^{\mathrm{e}}$ \\
\hline \multicolumn{3}{|c|}{ Flavan-3-ol monomers $(\mu \mathrm{mol} \mathrm{TE} / \mathrm{g})$} \\
\hline EGC & $5.28 \pm 0.59$ & $8.93 \pm 0.17$ \\
\hline CA & $1.44 \pm 0.14$ & $2.07 \pm 0.13$ \\
\hline EGCG & $5.61 \pm 0.32$ & $10.05 \pm 0.21$ \\
\hline EC & $1.47 \pm 0.18$ & $2.59 \pm 0.10$ \\
\hline ECG & $5.82 \pm 0.26$ & $9.50 \pm 0.90$ \\
\hline
\end{tabular}

* Mean values marked with different letters within the column are significantly different $(\mathrm{p} \leq 0.05)$. 
The RSA and CUPRAC results of the individual flavan-3-ol monomers ranged from 1.47 to 5.52 and from 2.07 to $10.05 \mu \mathrm{mol} \mathrm{TE} / \mathrm{g}$, respectively. The EGC, EGCG and ECG showed more antioxidant activity than EC and CA. The highest RSA and CUPRAC values were observed on the ECG and EGCG, respectively.

\section{Individual phenolic compounds in grape seeds}

The amounts of phenolic compounds in the grape seed extracts are presented in Table III and the 'Royal' seed extract HPLC-DAD chromatogram was indicated on Figure 4. The EGC, CA, EGCG, EC and ECG contents in the samples ranged from 1.23 to $6.53 \mathrm{mg} / \mathrm{g}$, from 11.61 to $80.20 \mathrm{mg} / \mathrm{g}, 0.21$ to 0.51 $\mathrm{mg} / \mathrm{g}$, from 2.78 to $48.26 \mathrm{mg} / \mathrm{kg}$ and from 0.08 to $1.50 \mathrm{mg} / \mathrm{g}$, respectively. These differences for phenolic compounds, except EGCG, were significant. The $\mathrm{CA}$ and $\mathrm{EC}$ were the major flavan-3-ols in the grape seeds.

'Cardinal' had the highest EGC, CA, EGCG, EC and ECG contents, while 'Cabernet Sauvignon' had the lowest ones.

The CA, which was the most abundant monomeric flavan-3-ol in grape seeds, allowed ranking the cultivars as follows: 'Cardinal' > 'Michele Palieri' > 'Alphonse Lavallee' > 'Mevlana' > 'Royal' > 'Ece' $>$ 'Italia' > 'Red Globe' > 'Cabernet Sauvignon'. The contents of EC, which was another major flavan-3-ol, decreased as follows: 'Cardinal' > 'Ece' $>$ 'Michele Palieri' > 'Mevlana' > 'Alphonse Lavallee' > 'Red Globe' > 'Royal' > 'Italia' > 'Cabernet Sauvignon'.

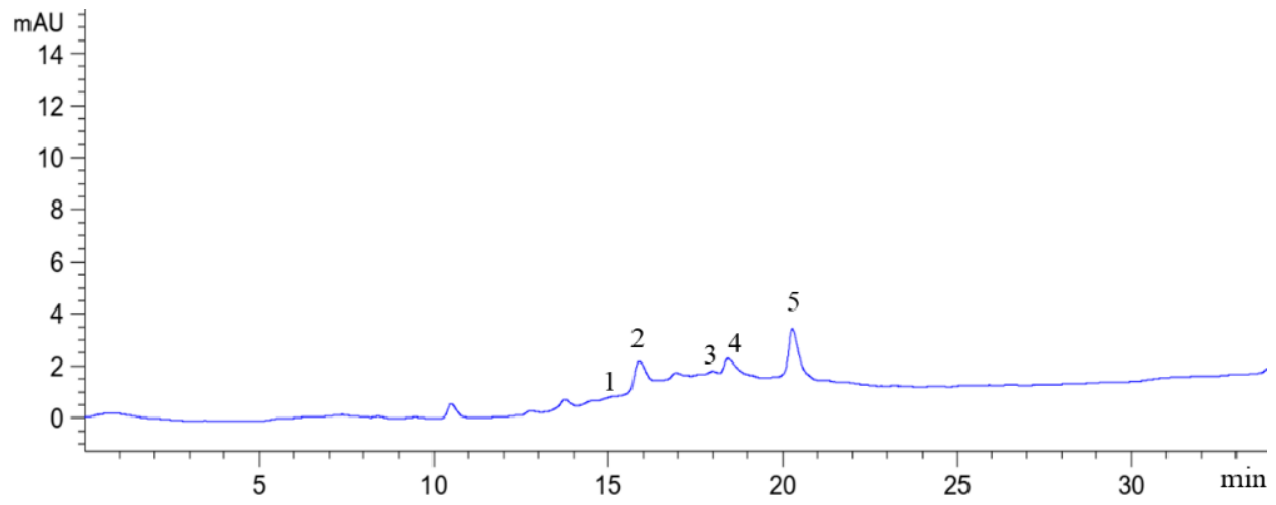

Figure 4. HPLC-DAD chromatogram of the flavan-3-ol monomers of the 'Royal' seed extract. 1: (-)-Epigallocatechin; 2: (+)-Catechin; 3: (-)-Epigallocatechin gallate; 4: (-)-Epicatechin; 5: (-)-Epicatechin gallate.

Table III

Phenolic compounds in the grape seeds $(\mathrm{mg} / \mathrm{g})$

\begin{tabular}{|c|c|c|c|c|c|}
\hline Cultivars & EGC & CA & EGCG & EC & ECG \\
\hline Cardinal & $6.53 \pm 1.26^{\mathrm{a}}$ & $80.20 \pm 0.18^{\mathrm{a}}$ & $0.51 \pm 0.16$ & $48.26 \pm 0.40^{\mathrm{a}}$ & $1.50 \pm 0.03^{\mathrm{a}}$ \\
\hline Michele Palieri & $5.82 \pm 1.19^{\mathrm{ab}}$ & $69.56 \pm 0.50^{\mathrm{b}}$ & $0.32 \pm 0.04$ & $36.20 \pm 0.93^{\mathrm{bc}}$ & $0.13 \pm 0.02^{\mathrm{f}}$ \\
\hline Mevlana & $3.71 \pm 0.64^{\mathrm{bcd}}$ & $56.31 \pm 0.12^{\mathrm{c}}$ & $0.34 \pm 0.06$ & $34.18 \pm 1.18^{\mathrm{c}}$ & $0.92 \pm 0.01^{\mathrm{c}}$ \\
\hline Italia & $4.70 \pm 0.99^{\mathrm{abc}}$ & $28.99 \pm 1.81^{\mathrm{e}}$ & $0.27 \pm 0.02$ & $9.74 \pm 0.71^{\mathrm{f}}$ & $0.24 \pm 0.05^{\mathrm{e}}$ \\
\hline Alphonse Lavallee & $3.18 \pm 0.78^{\mathrm{bcd}}$ & $64.75 \pm 2.88^{b}$ & $0.28 \pm 0.01$ & $26.61 \pm 1.63^{\mathrm{d}}$ & $1.01 \pm 0.01^{\mathrm{b}}$ \\
\hline Cabernet Sauvignon & $1.23 \pm 0.33^{\mathrm{d}}$ & $11.61 \pm 0.38^{\mathrm{g}}$ & $0.21 \pm 0.02$ & $2.78 \pm 0.48^{\mathrm{g}}$ & $0.08 \pm 0.03^{\mathrm{f}}$ \\
\hline
\end{tabular}

* Mean values marked with different letters within each column are significantly different $(\mathrm{p} \leq 0.05)$

CA and EC contents in 'Cabernet Sauvignon' seeds are in accordance with those reported by Baydar et al. (2011). On the other hand, these CA and EC averages of the other seed extracts were higher those found by Yilmaz and Toledo (2004), Bakkalbaşı et al. (2005), Mandic et al. (2008), Baydar et al. (2011) and Coklar (2017). Extraction can be one of the main factors causing these differences. In this study, an effective extraction method described by Shi et al. (2003) was used, with slight modifications. Besides, cultivar and environmental conditions could be the other effective factors. Bozan et al. (2008) showed that EGC ranged from 0.79 to $5.96 \mathrm{mg} / \mathrm{g}$, EGCG varied between 0.79 and $2.55 \mathrm{mg} / \mathrm{g}$, and ECG ranged 
from 0.32 to $11.50 \mathrm{mg} / \mathrm{g}$ in 11 grape seeds cultivated in Turkey. The EGC and ECG contents were reported as $1118-1434 \mathrm{mg} / \mathrm{kg}$ and $1309-3399 \mathrm{mg} / \mathrm{kg}$ in 'Ekşikara' grape seeds, respectively (Coklar, 2017). Kim et al. (2006) found $0.15-0.20 \mathrm{mg} / \mathrm{mL}$ of ECG and $0.11-0.15 \mathrm{mg} / \mathrm{mL}$ of EGCG in grape seed samples that were heated and used as whole and as powder and they stated that these heat treatments released phenolic compounds. The present study findings are in agreement with the results of this previous study. Moreover, Popov et al. (2017) expressed that CA ranged from 254 to $20959 \mu \mathrm{g} / \mathrm{g}$, EC from 543 to $16421 \mu \mathrm{g} / \mathrm{g}$, EGC from 219 to 1813 $\mu \mathrm{g} / \mathrm{g}$, and ECG from 41 to $2606 \mu \mathrm{g} / \mathrm{g}$ in grape seeds. In addition, $\mathrm{CA}$ and $\mathrm{EC}$ were found as major flavan-3-ol monomers with $51 \%$ and $34 \%$ in the grape seeds, respectively. EGC and ECG minor flavan-3-ols represented $6 \%$ and $4 \%$ of the grape seeds, respectively (Popov et al., 2017). In the current study, the CA, EC, EGC, ECG and EGCG percentages of the monomeric flavan-3-ols were $60.2 \%, 33.2 \%, 5.3 \%, 0.8 \%$ and $0.4 \%$, respectively. The results of CA, EC and EGC corroborate those of Popov et al. (2017).

\section{Correlations between antioxidant capacities and polyphenols}

The correlation coefficients between the antioxidant capacities, TP, TF and monomeric flavan-3-ols were indicated in Table IV. Significant correlations were found between TP, TF, RSA, CUPRAC and flavan-3-ols. According to the obtained results, TP was significantly correlated with $\mathrm{TF}(\mathrm{r}=0.856$, $\mathrm{p}<0.01)$. The highest positive correlation was observed between RSA and CUPRAC $(r=0.975$, $\mathrm{p}<0.01)$. TP contents of the grape seeds correlated strongly with RSA $(\mathrm{r}=0.926, \mathrm{p}<0.01)$ and CUPRAC $(\mathrm{r}=0.913, \quad \mathrm{p}<0.01)$. Similar correlations were reported by Guendez et al. (2005), Li et al. (2008) and Makris et al. (2007). In general, it is known that phenolic compounds contents are positively correlated with the antioxidant capacity. The results of the current study also support these correlations. $\mathrm{CA}$ and EGC contents were moderately correlated with RSA ( $\mathrm{r}=0.613, \mathrm{p}<0.01$ and $\mathrm{r}=0.607, \mathrm{p}<0.01$, respectively) and CUPRAC $(\mathrm{r}=0.577, \mathrm{p}<0.05$ and $\mathrm{r}=0.541, \mathrm{p}<0.05$, respectively). Bakkalbaş1 et al. (2005) found strong correlation between antiradical efficiency and total flavan-3-ol content $(\mathrm{r}=0.9168$, $\mathrm{p}<0.001$ ). The correlations between individual monomeric flavan-3-ols and antioxidant capacity found in this work are lower than the aforementioned one. The differences can be assigned to the total flavan-3-ol values that include all monomer, dimer, tetramer and more highly polymerized procyanidins and their antioxidant effects.

In addition, significant correlation between $\mathrm{CA}$ and EC contents of the grape seeds $(r=0.832, p<0.01)$ was observed. The EC content had significant correlations with EGC $(\mathrm{r}=0.680, \mathrm{p}<0.01)$, EGCG $(\mathrm{r}=0.618, \mathrm{p}<0.01)$ and ECG $(\mathrm{r}=0.668, \mathrm{p}<0.01)$. The results also showed that grape seed $\mathrm{TP}, \mathrm{TF}$ and flavan-3-ol contents presented significant correlations between them, and were associated with high antioxidant capacity.

Table IV

The correlations between antioxidant properties

\begin{tabular}{|c|c|c|c|c|c|c|c|c|c|}
\hline & TP & TF & RSA & CUPRAC & EGC & CA & EGCG & EC & ECG \\
\hline TF & $0.856^{* *}$ & 1.000 & - & - & - & - & - & - & - \\
\hline CUPRAC & $0.913^{* *}$ & $0.756^{*}$ & $0.975^{*}$ & 1.000 & - & - & - & - & - \\
\hline EGC & $0.665^{* *}$ & $0.642^{* *}$ & $0.607^{* *}$ & $0.541^{*}$ & 1.000 & - & - & - & - \\
\hline EGCG & 0.420 & $0.486^{*}$ & 0.359 & 0.339 & $0.690^{* *}$ & $0.504^{*}$ & 1.000 & - & - \\
\hline EC & $0.580^{*}$ & $0.757^{* *}$ & 0.461 & 0.407 & $0.680^{* *}$ & $0.832^{* *}$ & $0.618^{* *}$ & 1.000 & - \\
\hline ECG & 0.252 & 0.368 & 0.346 & 0.334 & 0.391 & 0.495 & $0.607^{* *}$ & $0.668^{* *}$ & 1.000 \\
\hline
\end{tabular}

Significant correlation at $0.01 * *$ or $0.05^{*}$ level.

\section{CONCLUSIONS}

The current study revealed the oil content, fatty acid profile, total phenolic and flavonoid contents, antioxidant activities and monomeric flavan-3-ols of nine widely grown different grape seeds in Turkey. Significant differences were found between the cultivars for the examined parameters. All grape seeds were rich in UFAs. The predominant fatty acid was linoleic acid, which presented the highest amount in 'Red Globe' seeds. This study showed that grape seeds had considerably antioxidants. 'Cardinal', 'Italia' and 'Michele Palieri' were the prominent cultivars for these compounds. The major monomeric flavan-3-ols were $(+)$-catechin and $(-)$-epicatechin in the grape seeds. Significant correlations between the analyzed characteristics were found. The highest positive correlation was observed between RSA and CUPRAC. Besides, 
these antioxidant capacities were also strongly correlated with TP and TF contents. These results support that the seeds of the examined grape cultivars are a potential source of unsaturated fatty acids and antioxidants that may have positive effects on human health. Furthermore, these findings could be useful not only for the food industry but also for breeding programs in order to select cultivars with higher levels of bioactive compounds.

\section{ACKNOWLEDGEMENTS}

The plant materials and laboratories of Manisa Viticulture Research Institute and Bati Akdeniz Agricultural Research Institute were utilized in this study.

CONFLICTS OF INTEREST: The authors declare no conflict of interest.

\section{REFERENCES}

Al Juhaimi F., Geçgel Ü., Gülcü M., Hamurcu M., Özcan M.M., 2017. Bioactive properties, fatty acid composition and mineral contents of grape seed and oils. S. Afr. J. Enol. Vitic., 38, 3-108.

AOAC, 2005. Association Official Analytical Chemist, Official Methods of Analysis. 18th edition, Horwitz W., Latimer GW. (ed.), AOAC International, Gaithersburg, Maryland.

Apak R., Guclu K., Ozyurek M., Karademir S.E., 2004. Novel total antioxidant capacity index for dietary polyphenols and vitamins $\mathrm{C}$ and $\mathrm{E}$, using their cupric ion reducing capability in the presence of neocuproine: CUPRAC method. J. Agric. Food Chem., 52, 7970-7981.

Bakkalbaşı E., Yemiş O., Aslanova D., Artik N., 2005. Major flavan-3-ol composition and antioxidant activity of seeds from different grape cultivars grown in Turkey. Eur. Food Res. Technol., 221, 792-797.

Baydar N.G., Babalık Z., Türk F.H., Çetin E.S., 2011. Phenolic composition and antioxidant activities of wines and extracts of some grape varieties grown in Turkey. J. Agric. Sci., 17, 67-76.

Baydar N.G., Özkan G., Çetin E.S., 2007. Characterization of grape seed and pomace oil extracts. Grasas y Aceites, 58, 29-33.

Beveridge T.H.J., Girard B., Kopp T., Drover J.C.G., 2005. Yield and composition of grape seed oils extracted by supercritical carbon dioxide and petroleum ether: varietal effects. J. Agric. Food Chem., 53, 1799-1804.

Bozan B., Tosun G., Özcan D., 2008. Study of polyphenol content in the seeds of red grape (Vitis Vinifera L.) varieties cultivated in Turkey and their antiradical activity. Food Chem., 109, 426-430.

Bucic-Kocic, A., Planinic M., Tomas S., Jakobek L., Seruga M., 2009. Influence of solvent and temperature on extraction of phenolic compounds from grape seed, antioxidant activity and colour of extract. Int. J. Food Sci. Technol., 44, 2394-2401.

Callaghan C.M., Leggett R.E., Levin R.M., 2013. A comparison of total antioxidant capacities of concord, purple, red, and green grapes using the CUPRAC assay. Antioxidants, 2, 257-264.
Coklar H., 2017. Antioxidant capacity and phenolic profile of berry, seed, and skin of Ekșikara (Vitis vinifera L) grape: Influence of harvest year and altitude. Int. J. Food Prop., 20, 2017-2087.

Da Porto C., Decorti D., Tubaro F., 2012. Fatty acid composition and oxidation stability of hemp (Cannabis sativa L.) seed oil extracted by supercritical carbon dioxide. Ind. Crops Prod., 36, 401-404.

Guendez R., Kallithraka S., Makris D.P., Kefalas P., 2005. Determination of low molecular weight polyphenolic constituents in grape (Vitis vinifera sp.) seed extracts: Correlation with antiradical activity. Food Chem., 89, 1-9.

Kim S.Y., Jeong S.M., Park W.P., Nam K.C., Ahn D.U., Lee S.C., 2006. Effect of heating conditions of grape seeds on the antioxidant activity of grape seed extracts. Food Chem., 97, 472-479.

Koç M., Gecgel U., Karasu S., Sivri G.T., Apaydi D., Gulcu M., Ozcan M.M., 2019. Valorisation of seeds from different grape varieties for protein. mineral. bioactive compounds content, and oil quality. Qual. Assur. Saf. Crop., 11, 351-359.

Li H., Wang X., Li P., Li Y., Wang H., 2008. Comparative study of antioxidant activity of grape (Vitis vinifera) seed powder assessed by different methods. J. Food Drug. Anal., 16, $1-7$.

Lima M.D., Silani I.D.V., Toaldo I.M., Correa L.C., Biasoto A.C.T., Pereira G.E., Bordignon-Luiz M.T., Ninow J.L., 2014. Phenolic compounds, organic acids and antioxidant activity of grape juices produced from new Brazilian varieties planted in the Northeast Region of Brazil. Food Chem., 161, 94-103.

Makris D.P., Boskou G., Andrikopoulos N.K., 2007. Polyphenolic content and in vitro antioxidant characteristics of wine industry and other agri-food solid waste extracts. $J$. Food Compos. Anal., 20, 125-132.

Mandic A.I., Dilas S.M., Cetkovic G.S., Canadanovic-Brunet J.M., Tumbas V.T., 2008. Polyphenolic composition and antioxidant activities of grape seed extract. Int. J. Food Prop., 11, 713-726.

Martin M.E., Grao-Cruces E, Millan-Linares M.C., Montserrat-de la Paz S., 2020. Grape (Vitis vinifera L.) Seed Oil: A Functional Food from the Winemaking Industry. Foods, 9, 1360.

Nakao M., Takio S., Ono K., 1998. Alkyl peroxyl radical-scavenging activity of catechins. Phytochemistry, 49, 2379-2382.

Nawaz H., Shi J., Mittal G.S., Kakuda Y., 2006. Extraction of polyphenols from grape seeds and concentration by ultrafiltration. Sep. Purif. Technol., 48, 176-181.

Ovcharova T., Zlatanov M., Dimitrova R., 2016. Chemical composition of seeds of four Bulgarian grape varieties. Ciência Téc. Vitiv., 31, 31-40.

Popov M., Hejtmankova A., Kotikova Z., Stralkova R., Lachman J., 2017. Content of flavan-3-ol monomers and gallic acid in grape seeds by variety and year. Vitis, 56, 45-48.

Sabir A., Unver A., Kara Z., 2012. The fatty acid and tocopherol constituents of the seed oil extracted from 21 grape varieties (Vitis spp.). J. Sci. Food Agric., 92, 1982-1987.

Shi J., Yu H., Pohorly J., Young J.C., Bryan M., Wu Y., 2003. Optimization of the extraction of polyphenols from grape seed meal by aqueous ethanol solution. J. Food Agric. Environ., 1, 42-47.

Singleton V.L., Rossi J.A., 1965. Colorimetry of total phenolics with phosphomolybdic-phosphotungstic acid reagents. Am. J. Enol. Vitic., 16, 144-158. 
Tangolar S.G., Özoğul Y., Tangolar S., Torun A., 2009. Evaluation of fatty acid profiles and mineral content of grape seed oil of some grape genotypes. Int. J. Food Sci. Nutr., 60, 32-39.

Wen X., Zhu M., Hu R., Zhao J., Chen Z., Li J., Ni Y., 2016. Characterisation of seed oils from different grape cultivars grown in China. J. Food Sci. Technol., 53, 3129-3136.

Yemis O., Bakkalbasi E., Artik N., 2008. Antioxidative activities of grape (Vitis vinifera) seed extracts obtained from different varieties grown in Turkey. Int. J. Food Sci. Technol., 43, 154-159.
Y1lmaz Y., Toledo R.T., 2004. Major flavonoids in grape seeds and skins: Antioxidant capacity of catechin, epicatechin, and gallic acid. J. Agric. Food Chem., 52, 255-260.

Zhishen J., Mengchneg T., Jianming W., 1999. The determination of flavonoids contents in mulberry and their scavenging effects on superoxide radicals. Food Chem., 64, $555-559$. 